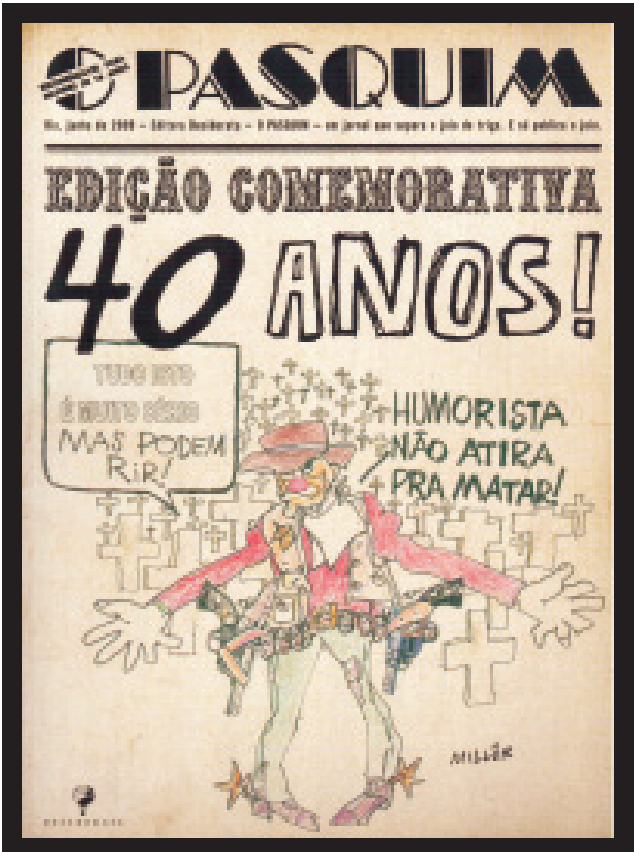

Pasquim 40 anos: Edição

Comemorativa. Rio de Janeiro:

Desiderata, 2009, 40 p.

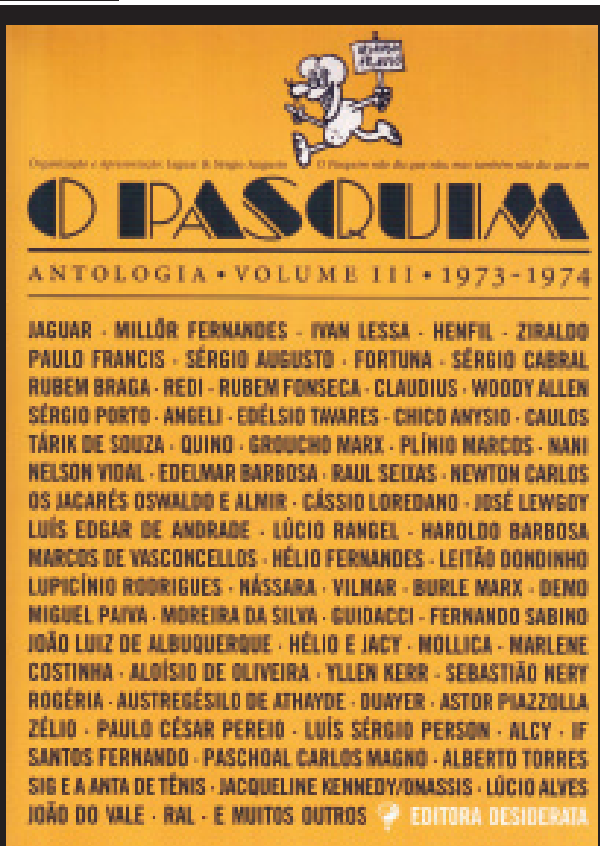




\section{O aniversário do Pasquim: 22 anos em 5}

Márcia NemeBuzalaf*

A importância do Pasquim na história da imprensa brasileira está registrada em suas imagens. Até seus textos eram imagéticos, na medida em que eram cheios de símbolos gráficos e compunham as páginas como um quadro, sem muita coerência ou explicação. O jornal foi publicado durante mais de 20 anos, em diferentes condições de produção, e ultrapassou quase trezentas edições sob censura prévia e sob o rótulo de ser alternativo. Lançado em 16 de junho de 1969, foi formado por importantes jornalistas, ilustradores, humoristas e escritores brasileiros e brasilianistas. Adotou o humor como linha editorial e registrou a força de uma geração.

A tímida comemoração sobre o quarentenário do lançamento do Pasquim, em 2009, perdeu-se no meio das notícias sobre a propagação do vírus da gripe A e a morte do ídolo pop Michael Jackson. Três publicações da editora Desiderata, porém, trouxeram de volta a importância das imagens no semanário carioca que retratam uma geração. São elas: Pasquim 40 anos: Edição Comemorativa, Antologia do Pasquim - Volume III e a reedição de O Som do Pasquim, originalmente publicado em 1976 pela Editora Codecri.

Este último foi organizado por Tárik de Souza, que também escreve um prefácio explicando alguns detalhes sobre as famosas entrevistas. Apenas Roberto Carlos e Maria Bethânia não autorizaram a reprodução de suas conversas com o Pasquim, e Agnaldo Timóteo pediu uma retratação na sua entrevista, já que havia questionado, na década de 70 , a competência musical de Chico Buarque, Caetano Veloso e Milton Nascimento.

*Doutora em História pela Universidade Estadual Paulista (Unesp). 
Os outros dois lançamentos, estes sim, obras inéditas, trazem a força do jornal através de suas imagens. Pasquim 40 anos: Edição Comemorativa centraliza suas 40 páginas em 31 capas marcantes do semanário. A escolha não parece ter um padrão, visto que as capas fielmente reproduzidas no livro não representam as diferentes fases de existência do jornal. Sem exceção alguma, todas as escolhidas foram publicadas durante o período mais criativamente tumultuado do jornal: entre seu lançamento, em 1969, e o fim da censura prévia, no início de 1975.

$\mathrm{Na}$ abertura do livro, uma tirinha feita por Jaguar sobre os 40 anos do jornal e dois textos de abertura visam situar o leitor em relação ao objetivo da publicação. O primeiro artigo, de Chico Caruso, menciona, sem maiores detalhes, a existência de um júri responsável por eleger as capas e explica a edição de número 34, de fevereiro de 1970, reproduzida ao lado do texto. Na imagem, Sig, o mascote do jornal, criado pelo ilustrador Jaguar, aparece em um campo colhendo vários asteriscos parecidos com flores. Eé Caruso quem explica a utilização constante dos asteriscos no lugar dos palavrões amplamente falados pelos entrevistados do Pasquim.

A troca simbólica das palavras de baixo calão pelo tipo gráfico * foi publicada primeiramente em uma das capas mais representativas do semanário e como um recurso para burlar a censura. As entrevistas eram publicadas em forma de conversa, com perguntas, respostas e comentários (a chamada entrevista ping-pong), o que ainda não era utilizado em nenhum jornal brasileiro. E, como Leila Diniz, a atriz que ocupa a capa da edição de número 22 (publicada em novembro de 1969), usou e abusou dos palavrões, estes foram substituídos por asteriscos com um aviso expresso dos editores no miolo do jornal. Esta capa também é reproduzida na página 12 do livro comemorativo e mostra vários elementos constantes no Pasquim: símbolos gráficos, cabeçalho móvel, humor e o ratinho Sig comentando a edição.

Já o artigo Millôr Fernandes (que trabalhou no jornal até o fim da censura) também faz uma apresentação com algumas informações sobre 
as capas que se seguem. Questiona e, ao mesmo tempo, enaltece a notoriedade que o semanário teve e continuou tendo ao longo dos últimos 40 anos. Além disso, Millôr explica que as capas do Pasquim não tinham a função tradicional dos outros jornais. "Serviam apenas para sacanear", diz o ilustrador que, desta forma, abre espaço para a reprodução fiel das capas do período.

São capas históricas, polêmicas e até enigmáticas, que mostram a participação da geração que ajudou a fazer o semanário - seja como personagem ou colaboração direta na edição. Os nomes dos escritores e ilustradores que produziram as edições durante a prisão dos seus membros, em 1971, estão lá, assim como o nome dos jornalistas detidos na Vila Militar do Rio de Janeiro.

A amostra escolhida para a edição comemorativa consegue refletir a diversidade de estilos do Pasquim sob censura, que tinha pouco - ou quase nenhum - padrão para a diagramação da capa. Encontramos o cabeçalho do jornal no topo da página, no meio e até no final - "Esta capa é pra satisfazer os que queriam ver o Pasquim por baixo", ironiza uma delas. E estas frases-editoriais que acompanhavam o cabeçalho do jornal também ajudam a entender o período e a produção da chamada "patota". Um registro editorial que ainda era restrito a bibliotecas.

As capas são monotemáticas ou multicomunicativas: trazem uma, dez ou nenhuma "chamada" principal, mas cravam a linguagem visual e verbal que representa uma geração formada por diferentes grupos culturais que conviviam no Rio de Janeiro e tinham, no Pasquim, um espaço para suas produções e reflexões.

São imagens que, ainda hoje, surpreendem os olhos acostumados com o jornalismo politicamente correto e graficamente coerente. Com improviso e falta de padrão, o jornal ajudou a posicionar a naturalidade da oralidade e das gírias no papel impresso pela primeira vez. Entretanto, a edição comemorativa tem seu caráter festivo - para usar um termo da época - de exaltar as capas sem comentários e/ou explicações sobre o processo de produção de cada uma daquelas capas. É uma oportunidade de registrar a memória dos jornalistas. 
Já o outro lançamento da Desiderata, Antologia do Pasquim Volume III, é bem mais completo, apesar de também ser concentrado na reprodução do material original. A edição fecha uma trilogia que mostra páginas, textos, entrevistas, ilustrações e capas do semanário carioca. O primeiro volume foi publicado em 2006, e corresponde aos anos de 1969 a 1971, período em que o jornalista Tarso de Castro, fundador do Pasquim, trabalhou no jornal; o segundo volume, lançado em 2007, envolveu o período de 1972 e 1973, quando a censura ainda era feita no Rio de Janeiro; e esta terceira Antologia, publicada no mês de aniversário dos 40 anos do lançamento do semanário, edita materiais de 1973 e 1974, quando a censura prévia passou a ser feita em Brasília e as dificuldades de produção do jornal aumentaram consideravelmente.

Sérgio Augusto e Jaguar são os organizadores dos três volumes que trazem um material quase intacto: mantiveram os erros gramaticais, a falta de crédito e a originalidade intocada dos quadrinhos e charges. A única alteração feita durante a edição das obras foi a atualização da ortografia de algumas palavras apenas nos textos.

Diferentemente das anteriores, na terceira Antologia do Pasquim, apenas Sérgio Augusto escreve o texto de apresentação. E é nele que o jornalista situa a produção daquele período, explicando, em algumas linhas definitivas, os meandros da relação com as diferentes formas de censura que incidiu sobre o semanário.

Até o final de 1973, os censores eram cariocas e mantinham, de alguma forma, uma negociação com os jornalistas do Pasquim sobre o que era ou não publicado - e como seria publicado. Marina Brum Duarte - a conhecida Dona Marina, também responsável por censurar algumas músicas de Chico Buarque - lia e rasurava o material do semanário na própria redação, e ficou conhecida pelo gosto, compartilhado com os jornalistas, por uísque escocês. Foi destituída em novembro de 1970 porque liberou, sem maiores questionamentos, uma montagem feita com imagem de Pedro Américo, "O Grito do Ipiranga", na qual Jaguar trocou o famoso "Independência ou morte" 
por um balãozinho com uma frase da música de Jorge Ben, "Eu quero é Mocotó", em novembro de 1970. Além da mudança do executor da censura, a imagem também foi responsável pela prisão de onze jornalistas do jornal durante dois meses.

O outro censor do Pasquim, e lembrado no texto de apresentação, o general Juarez Paz Pinto, lia e censurava os textos de Paulo Francis vindos de Nova Iorque nas areias de Copacabana. Também foi afastado de seu ofício quando não percebeu a "subversão" de uma entrevista publicada pelo semanário. Na edição de número 227, Ângela Gillian, antropóloga americana e negra, afirmou ter visto muito preconceito racial no Brasil. A entrevista ficou famosa porque nem o aclamado goleador Pelé foi poupado; a pesquisadora disse que o rei do futebol se casara com uma mulher branca para "melhorar a raça" e, de uma forma mais generalista, ascender socialmente. Como o general Juarez não questionou em nenhum momento as afirmações de racismo no país, a conversa foi publicada integralmente, mas, logo depois, causou o efeito mais indesejado para a equipe: o Pasquim passou a ser censurado fora do Rio de Janeiro. E, como relembra Sérgio Augusto, "até inocentes fotos de Pixinguinha foram rasuradas". O general Antonio Bandeira havia determinado: "Agora não sai mais preto nesse jornal".

A relação com a censura ficou, assim, mais evidente. O próprio jornalista falou da "barganha" com os militares cariocas sobre o que seria ou não publicado, que acabou quando a censura foi transferida para o "longínquo, impessoal, implacável e inacessível Centro de Informações do Exército, em Brasília". Com o CIEX, nenhuma negociação era permitida. Pior: como o transporte consumia um tempo significativo, a produção do jornal precisava ser feita com um material excedente que pudesse suprir os possíveis cortes ou demoras na devolução.

A matemática das edições do Pasquim sob censura é difícil de ser entendida, mas a terceira Antologia dá conta de explicar alguns parâmetros. Primeiramente, o humor continuou sendo tanto a linha 
editorial quanto a possibilidade de existência do semanário nas diferentes fases de censura pelas quais passou. Isto fica claro em várias seções que mantiveram sua força, como as Dicas do Pasquim e as personagens clássicas de Henfil e Ziraldo. Em segundo lugar, a cobertura internacional virou foco dos correspondentes do jornal durante a censura brasiliense; uma "válvula de escape", como relata Sérgio Augusto. O caso Watergate, a guerra do Vietnã e textos de Woody Allen eram pautas constantes, alimentadas, principalmente, pelos jornalistas exilados no exterior durante o período - principalmente Paulo Francis e Henfil, em Nova Iorque, e Ivan Lessa, em Londres.

Não há explicação alguma sobre os motivos de se ter reproduzido apenas a produção do semanário durante o período de censura. Aliás, os três livros comemorativos reproduzem material restrito à fase da censura, assim como os três volumes da Antologia do Pasquim. Se o jornal perdeu o deboche quando se engajou nas campanhas pela anistia e pelas eleições diretas, não se sabe, nem se discute nas apresentações dos livros. Se os 22 anos de existência do Pasquim podem ser resumidos em apenas cinco, eu concordo com os organizadores. Mas a única garantia que temos, ao ter contato com o conteúdo de várias edições do jornal, é que, por coincidência, afinidade ou mera curtição de Ipanema, foi justamente na fase de censura que o jornal agregou nomes importantes e vertentes artísticas que ecoam até hoje na produção cultural do Brasil, mostrando o lugar da geração de 60 no Pasquim, e do Pasquim na geração de 60. 